Jurnal Ilmiah Iqra'

2541-2108 [Online] 1693-5705 [Print]

Tersedia online di: http://journal.iain-manado.ac.id/index.php/JII

\title{
Analisis Kritis Undang-Undang Sisdiknas Nomor 20 Tahun 2003
}

\author{
Matlani \\ Institut Agama Islam Negeri Madura \\ Emlani47@gmail.com
}

\author{
Aan Yusuf Khunaifi \\ Sekolah Tinggi Ilmu Syariah Faqih Asy'ari, Kediri. \\ aankhunaifi13@gmail.com
}

\begin{abstract}
Abstrak
Pendidikan dalam suatu Negara merupakan salah satu bagian terpenting yang selalu mendapatkan perhatian yang cukup serius, pendidikan di indonesia dari waktu kewaktu mengalami perubahan dan peningkatan secara segnifikan, segala bentuk kebijakan pendidikan akan tertuang dalam sistem pendidikan Nasional, kebijakan tersebut tidak lain merupakan hasil pemikiran dari para tokoh pendidikan dengan tujuan bagaimana sistem pendidikan nasional mampu menyatukan sebuah konsep terhadap kebutuhan masyarakat, maka pendidikan nasional secara kolektif harus mampu melakukan perubahan dengan mewujudkan bangsa yang cerdas dan bermartabat dengan berkemampuan yang luas, spiritual yang tinggi serta mempunyai akhlak yang mulia.

Salah satu kebijakan pemerintah yang mendapat kritik dan penolakan oleh elemen masyarakat dan para elit pendidikan adalah UU Sisdiknas tahun 2003 yang memuat tentang sistem pendidikan Nasional, pemerintah pada saat penetapkan undangundang nomor 20 tahun 2003 dengan serta merta tanpa mengkaji secara mendalam dengan berbagai pertimbangan, sehingga diskriminasi terhadap bangsa indonesia kerap terjadi. Indonesia memiliki asas keadilan yang hal tersebut harus diperhatikan oleh seluruh pihak pemerintah sebagai pemimpin bangsa, namun dalam muatan UU nomor 20 tahun 2003 terdapat beberapa hal yang tidak sesuai dengan realitas dan merugikan ke satu pihak. Maka dengan demikian undang-undang Sisdiknas sebagai hasil pemikiran yang di tetapkan sebagai kebijakan pemerintah yang akan mengatur tertang sistem pendidikan nasional di harapkan mampu menyatu dengan masyarakat dan mempunyai prinsip keadilan tanpa diskriminasi.
\end{abstract}

Kata kunci : Analisis; Undang-Undang Sisdiknas 


\begin{abstract}
Education in a country is one of the most important parts that always get quite serious attention, education in Indonesia from time to time changes and increases significantly, all forms of education policy will be contained in the National education system, the policy is nothing but the result of the thoughts of the education leaders with the aim of how the national education system is able to unite a concept of the needs of the community, then the national education as a collective must be able to make changes by creating an intelligent and dignified nation with broad, high spiritual abilities and noble character.

One of the government policies that have been criticized and rejected by elements of the community and the education elite is the 2003 National Education System Law which contains the National Education System, the government at the time of enacting Law number 20 of 2003, without necessarily reviewing it in depth with a variety of considerations, so that discrimination against the Indonesian nation often occurs. Indonesia has the principle of justice which must be considered by all government parties as the nation's leader, but in the content of Law number 20 of 2003 there are several things that are not in accordance with reality and are detrimental to one party. Therefore the National Education System Law as a result of thought is determined as a government policy that will regulate the national education system. It is expected to be able to unite with the community and have the principle of justice without discrimination.
\end{abstract}

Keywords : Analysis; Undang-Undang Sisdiknas

\title{
Pendahuluan
}

Semakin majunya perkembangan zaman telah merubah pola hidup masyarakat menjadi modern, adanya globalisasi menuntut lembaga pendidikan terus berkembang menyesuaikan kebutuhan masyarakat, jika lembaga pendidikan tidak mampu mengakomodasi tuntutan masyarakat maka tidak mustahil ia akan terkucilkan dan dengan sendirinya akan mati bersama pudarnya kepercayaan masyarakat. Maka tidak salah kemudian jika perguruan tinggi memilih diam tanpa harus melakukan relasi yang kuat sudah dapat dipastikan ia akan mengalami masa dimana ia berada dalam gerbong stagnasi.

Demokrasi pendidikan mempunyai konsekuensi logis bagi terbentuknya desentralisasi kewenangan pengelolaan pendidikan, pengelolaan pendidikan akan banyak ditentukan oleh pelaksana langsung, baik birokrat pendidikan, tenaga pendidik dan kependidikan, maupun masyarakat dalam menciptakan isi metode, alat, lingkungan, serta strategi belajar mengajar yang ujungnya adalah mengembangkan kualitas peserta didik menjadi sosok warga negara yang unggul (Rohman, 2010). 
Adanya kebijakan otonomi pendidikan merupakan salah satu sinyal positif bagi setiap lembaga pendidikan dalam upaya membangkitkan semangat untuk bersaing, dimana lembaga pendidikan diberikan kebebasan untuk berkreasi dan mengembangkan diri sesuai dengan apa yang diinginkan, pengelolaan lembaga pendidikan menjadi tanggung jawab oleh setiap pemegang lembaga pendidikan, sehingga partisispasi masyarakat dalam hal ini akan semakin meningkat dan semakin luas untuk memberikan masukan terhadap perkembangan lembaga pendiidkan.

Pendidikan dalam suatu Negara merupakan salah satu bagian terpenting yang selalu mendapatkan perhatian yang cukup serius, pendidikan di indonesia dari waktu kewaktu mengalami perubahan dan peningkatan secara segnifikan, segala bentuk kebijakan pendidikan akan tertuang dalam sistem pendidikan Nasional, kebijakan tersebut tidak lain merupakan hasil pemikiran dari para tokoh pendidikan dengan tujuan bagaimana sistem pendidikan nasional mampu menyatukan sebuah konsep terhadap kebutuhan masyarakat, maka pendidikan nasional secara kolektif harus mampu melakukan perubahan dengan mewujudkan bangsa yang cerdas dan bermartabat dengan berkemampuan yang luas, spiritual yang tinggi serta mempunyai akhlak yang mulia.

Pendidikan di Indonesia harus diupayakan dapat mempersatukan bangsa Indonesia, dengan berbagai upaya, antara lain pendidikan harus merata, seluruh anggota masyarakat berhak sekaligus wajib untuk belajar, segala dan kemampuan bangsa indonesia ini harus diarahkan untuk menopang pendidikan yang merata (Komite Rekonstruksi Pendidikan DIY, 2009). Jadi asas keadilan harus menjadi dasar utama dalam penyelenggaraan pendidikan.

Sebagai salah satu jalan yang dapat ditempuh untuk mewujudkan bentuk upaya tersebut ialah dengan pengambilan keputusan yang profesional oleh para tokoh dan menteri pendidikan dengan berbagai sistem. Setiap ide pemerintah atau pakar pendidikan yang melahirkan sebuah kesimpulan pokok yang memuat tentang pendidikan dan dituangkan dalam bentuk undang-undang maka hal tersebut merupakan kebijakan yang harus di jadikan sebagai acuan oleh semua pihak pendidikan dalam menjalankan suatu tindakan, hal tersebut merupakan tuntutan yang harus dipenuhi dalam rangka mencapai sebuah tujuan.. Maka pengambilan keputusan tersebut sebagai kebijakan sekaligus aturan yang harus di ikuti oleh semua elamen pendidikan, baik pendidikan dasar, menengah, maupun pendiidkan tinggi. 
Sudah seharusnya bagi pemangku kebijakan pendidikan untuk terus melakukan terobosan baru dalam upaya meningkatkan kualitas pendidikan, perubahan undang-undang sistem pendidikan nasional terus berjalan walau pada hakikatnya tidak dirubah secara total. Pada dasarnya perumusan dan implementasi sistem pendidikan nasional merupakan langkah strategis pemerintah untuk mengimbangi perubahan zaman, pendidikan saat ini dituntut untuk mampu bersaing baik dalam konteks nasional maupun inter nasional. Maka dari itu upaya pemerintah dalam konteks pendidikan tentu mengarah kepada proses pengembangan yang mana pengembangan tersebut diharuskan kepada semua lembaga pendidikan harus mengikuti sistem dan standarisasi pendidikan nasional yang telah ditentukan pemerintah, hal tersebut sebagaimana yang diamanatkan oleh undang-undang nomor 19 tahun 2005 tentang standar pendidikan nasional yang disingkat dengan (SNP), yang secara substantif memuat tentang standar minimal bagi semua lembaga pendiidkan baik dari tingkat pendiidkan dasar, menengah sampai tingkat perguruan tinggi.

Sistem pendidikan di Indonesia telah mengalami beberapa perubahan, perubahan tersebut sebagai kebijakan pemeritah yang harus di sadari dan di ikuti oleh semua elemen masyarakat, namun yang menjadi sebuah persoalan adalah tidak semua kebijakan yang di keluarkan pemerintah mendapat tanggapan positif, bahkan ada banyak kalangan dan elit pendidikan dengan melakukan kajian kritis sehingga ia menolak adanya kebijakan tersebut karena dianggap tidak sesuai dengan nilai-nilai bangsa negara Indonesia.

Salah satu kebijakan pemerintah yang mendapat kritik dan penolakan oleh elemen masyarakat dan para elit pendidikan adalah UU Sisdiknas tahun 2003 yang memuat tentang sistem pendidikan Nasional, pemerintah pada saat penetapkan undang-undang nomor 20 tahun 2003 dengan serta merta tanpa mengkaji secara mendalam dengan berbagai pertimbangan, sehingga diskriminasi terhadap bangsa indonesia kerap terjadi. Indonesia memiliki asas keadilan yang hal tersebut harus diperhatikan oleh seluruh pihak pemerintah sebagai pemimpin bangsa, namun dalam muatan UU nomor 20 tahun 2003 terdapat beberapa hal yang tidak sesuai dengan realitas dan merugikan ke satu pihak. Maka dengan demikian undangundang Sisdiknas sebagai hasil pemikiran yang di tetapkan sebagai kebijakan pemerintah yang akan mengatur tertang sistem pendidikan nasional di harapkan mampu menyatu dengan masyarakat dan mempunyai prinsip keadilan tanpa diskriminasi. 
Persoalan yang cukup mendasar dalam sistem pendidikan dalam realitasnya adalah ketidak sesuaian dalam kebijakan dengan prinsip-prinsip negara, selain tersebut terkadang terkadang dalam suatu kebijakan bertentangn dengan kebijakan yang lain, hal tersebut dipicu oleh isu-isu politik yang diiringi dengan unsur kepentingan, maka tidak salah kemudian jika kebijakan sistem pendidikan selalu berubah-ubah, konsistensi pemerintah terhadap suatu kebijakan seringkali menimbulkan banyak persoalan, maka dalam menyalurkan visi dan misi pendidikan mengalami kendala.

Undang-undang sisdiknas mempunyai fungsi yang begitu mendasar, yaitu bagaimana undang-undang tersebut mampu menyalurkan visi dan misi pendidikan Nasional, keberhasilan pendidikan akan ditentukan oleh bagaimana sistem pendidikan menampilkan eksistensinya. Maka jika sebuah sistem secara implemintatif memunculkan kontradiktif, maka sistem tersebut perlu di pertanyakan keberadaannya, oleh karena itu pemakalah akan membahas lebih mendalam sebgai mana rumusan masalah sebagai berikut.

\section{Rumusan Masalah.}

1. Bagaimanakah Implementasi UU Sisdinas nomor 20 tahun 2003?

2. Bagaimanakah kajian Analisis seputar Pendidikan Agama sebagai Kepentingan politik pada UU Sisdiknas nomor 20 tahun 2003?

3. Bagaimana kajian secara teknis dari UU Sisdiknas nomor 20 tahun 2003?

4. Bagaimana Kajian secara substansial dari UU Sisdiknas nomor 20 tahun 2003?

\section{Tujuan Pembahasan.}

1. Mendiskusikan Kontroversi Implementasi UU Sisdinas nomor 20 tahun 2003.

2. Mengkaji dan menganalisis seputar Pendidikan Agama sebagai Kepentingan politik pada UU Sisdiknas nomor 20 tahun 2003

3. Untuk memahami dan mendiskusikan teknis dari UU Sisdiknas nomor 20 tahun 2003

4. Untuk Memahami dan mendiskusikan substansi dari UU Sisdiknas nomor 20 tahun 2003 


\section{Kajian Teori}

\section{Kajian Kontroversi Implementasi Undang-undang Sisdiknas Nomor 20 Tahun 2003}

Implementasi sebuah undang-undang merupakan suatu hal yang tidak lepas dari sebuah problema, yang mana problema tersebut meniscayakan dua aliran yang bertolak belakang, ada yang pro dan juga ada yang kontra, hal tersebut tidak bisa dielakkan oleh pemerintah dalam melakukan sebuah kebijakan baru, idealnya kebijakan yang dikeluarkan pemerintah seharusnya mendapatkan respon positif dan diakui oleh semua kalangan elit politik maupun masyarakat bahwa sehingga kebijakan yang ada dapat menjadi acuan dan pemersatu bangsa untuk menuju bangsa yang multikultural. Kenapa undang-undang bisa ditolak oleh masyarakat?, apa yang menjadi penyebab dari penolakan tersebut. Pertanyaan itu merupakan pertanyaan mendasar dalam kajian analisis kontoversial terhadap kebijakan.

Setidaknya ada dua penyebab terjadinya penolakan masyarakat terhadap perubahan yang berkaitan dengan implementasi kebijakan. Pertama, adanya kekhawatiran masyarakat terhadap hadirnya perubahan. Kedua, penolakan masyarakat terhadap upaya implementasi kebijakan juga disebabkan oleh kurangnya informasi yang diterimanaya berkenaan dengan kebijakantersebut. Lebih-lebih bila informasi yang didapatkannya masih setengah-setengah dan bersifat menyesatkan sehingga memungkinkan terjadinya misinformasi atau misinterpretasi (Rohman, 2010).

Ketetapan undang-undang sisdiknas 2003 adalah upaya mencapai cita-cita bersama yang melalui usaha politik, dimana permerintah merumuskan undangundang tersebut bermaksud ingin mengangkat bangsa kearah yang lebih mulia, adanya globalisasi sebagai alasan yang konkrit bagi pemerintah untuk merumuskan undang-undang tersebut namun pada kenyataannya yang terjadi dilapangan menuai kritik yang memanas, pihak yang pro dan yang kontra sama-sama mempertahankan aspirasinya.

Menurut Ahmad Barizi setidaknya ada dua penyebab kenapa kemudian undang-undang sisdiknas 2003 menuai pro dan kontra.

1. RUU sisdiknas mengemuka kali pertama karena adanya dua versi: versi DPR (27 Mei 2003) dan versi (pemerintah 20 dan 28 Februari 2003). Adanya dua versi ini kemudian melahirkan polemik yang membawa kontroversi dan 
kecurigaan dimasyarakat, masyarakat menilai bahwa pembahasan RUU itu baik di DPR maupun di pemerintah sarat akan kepeentingan politik. Didalamnya dinilai mengandung sekian ambisi dan keinginan politik yang tersembunyi.

2. RUU sisdiknas dinilai oleh mereka yang kontra bahwa negara ingin mengambil alih peran keluarga secara menyeluruh dalam konteks pendidikan agama. UU pendidikan yang sejatinya perlu membangun sistem pendidikan yang membebaskan (fredom for) dipandang menjadi kerdil karena terjebak pada sentralisme yang terlalu kuat (pasal 58 ayat 2 , pasal 61 dan pasal 63). Dalam konteks pendidikan agama RUU dikesankan sebagai upaya untuk melindungi anak didik dari latar belakang islam untuk tidak dimurtadkan oleh sekolahsekolah kristen di mana mereka belajar disana.

3. RUU Sisdiknas mengesankan mengebiri dan mengkerdilkan anak didik dalam pengetahuan keagamaan, dalam pandangan mereka anak didik dinilai hanya di perkenankan mempelajari dan memahami agamanya sendiri (Barizi, 2011).

Dari tiga alasan mendasar di atas dapat di fahami bahwa dalam penerapan UU Sisdiknas sarat akan kepentingan, politik menjadi alasan utama kenapa di sektor eksekutif dan legislatif mengalami perbedaan pandangan sehingga melahirkan dua versi, hal itu menjadi alasan kuat bagi masyarakat dalam melakukan sebuah penilaian terhadap RUU Sisdiknas yang di klaim bahwa kebijakan tidak lagi memihak terhadap kepentingan bangsa, sentralisasi merupakan perampasan hak bangsa jika pendidikan agama menjadi tanggung jawab pemerintah, dan Ironisnya lagi asumsi yang terjadi adalah isu agama yang merupakan penyebab dari penolakan terhadap RUU Sisdiknas karena dianggap akan mngkerdilkan pemahaman peserta didik terhadap agama, ia akan cendrung terhadap agamanya tanpa melihat dan memahami agama lain sehingga toleransi dan multikulturalisme tidak akan terjadi pada proses pendidikan.

Dalam UU ini, kita melihat paradigma pendidikan yang tidak jelas orientasinya untuk pendidikan yang memanusiakan manusi yang berkemanusiaan, berkeadilan, memiliki kometmen untuk membangun proses belajar yang terus menerus, realitasnya dalam UU ini paradigma seperti dinafikan, ada kesan kuat bahwa UU ini bukan berbicara tentang pendidikan melainkan nuansa keagamaan yang diperkental dan diperkuat, naif bahwa pendidikan direduksi dalam kepentingan keagamaan yang orientasinya tidak jelas (Susetio, 2005). 
Pada dasarnya menurut Hadari Nawawi bahwa dirumuskan dan ditetapkannya perundang-undangan dimaksudkan untuk diterima anggota masyarakat, dalam dalam bentuk prilaku mentaatinya, ketentuan perundangundangan dirumuskan dan ditetapkan bukan untuk dilanggar secara sengaja oleh anggota masyarakat (Nawawi, 2004). Maka dengan demikian jika kebijakan pemerintah dalam proses implementasinya sudah mengalami persoalan maka selanjutnya yang akan terjadi dilapangan tentu penyimpangan-penyimpangan yang dilakukan oleh masyarakat khususnya bagi yang tidak sepakat terhadap kebijakan tersebut, idealnya bahwa perumusan kebijakan sepenuhnya harus diterima oleh semua kalangan agar bentuk diskriminasi tidak terjadi. Ponolakan yang terjadi merupakan bentuk restorasi yang perlu mendapatkan perhatian dari pemerintah, jika hal tersembut dibiarkan maka pendidikan akan keluar dari tujuan nilai nilai pancasila.

\section{Diskusi Seputar Pendidikan Agama Sebagai Kepentingan Politik}

Telah dibahas sedikit di atas terkait dengan polemik yang mengarah kepada pemahaman-pemahan yang menilai terkait eksistensi kebijakan UU Sisdiknas nomer 20 tahun 2003, dimana pada pasal 12 ayat 1 yang berbunyi "setiap peserta didik pada satuan pendidikan berhak mendapatkan pendidikan agama sesuai dengan agama yang dianutnya, dan diajarkan oleh pendidik yang seagama".

Pada ayat ini terjadi perdebatan yang begitu hangat dari berbagai kalangan intlektual muda, bagi yang menolak terhadap pasal ini secara rasional ia mengatakan bahwa telah tejadi pemaksaan dan juga formalisasi keagamaan bagi anak didik, dan itu melanggar kebebasan beragama, hak asasi manusia, dan toleransi beragama, sebagian dari upaya menciptakan kehidupan yang harmonis (Barizi, 2011).

Namun jika pendidikan agama dijadikan suatu muatan mata pelajaran disekolah maka menurut Benny susetyo bahwa pendidikan agama yang bersifat menonjol akan mengintervensi peran negara kepada masyarakat untuk menentukan pola pendidikannya teracuni oleh kepentingan-kepentingan politik jangka pendek, padahal konstitusi diarahkan untuk memenuhi tujuan jangka panjang, akibatnya nalar dimatikan atas nama perseteruan politik versus agama (Susetio, 2005). 
Alasan terkait dengan penolakan tersebut atas nama HAM cukup menarik, dimana dalam piagam hak asasi manusia artikel 18 human right 1948, pernyataan “ hak atas kemerdekaan, berpikir, bernurani dan beragama" meliputi: (1), kemerdekaan berganti agama, kepercayaan, (2) kemerdekaan untuk menghayati agama dan kepercayaan dalam pengajaran, praktik, ibadah, dan pelaksanaan aturan (Susetio, 2005). Jadi jelas bahwa dimanakah letak hak beragama dan hak mendapatkan pendidikan agama, jadi penerapan pasal di atas telah melanggar hak asasi manusia secara utuh.

Namun benarkah demikian, mari kita lihat pendapat yang mendukung adanya pendidikan agama bagi peserta didik dalam setiap satuan pendidikan, Malik Fajar, Mendiknas RI kabinet gotong royong justru memberi keleluasaan kepada anak didik untuk mendapatkan pelajaran agama sesuai agama yang dianut. Anak didik secara bebas dan merdeka diberikan hak otonomi dalam menentukan pilihan agama dan memperoleh pelajaran agama yang diyakininya disekolah (Barizi, 2011). Maka dengan demikian bukankah perintah secara leluasa memberikan kebebasan kepada masyarakat untuk memilih agamanya sesuai dengan keyakinan, jika kritik yang muncul adalah terkait dengan perampasan hak bagi keluarga, tentu hal tersebut tidak sama sekali, karena adanya pasal di atas tentu pemerintah justru ingin mendampingi, menfasilitasi, dan mengukuhkan agama mereka yang sesuai dengan keyakinannya sesuai dengan norma yang berlaku.

Pendidikan yang diangankan dalam UU sisdiknas sebenarnya bagaimana agama memiliki pengaruh yang signifikan bagi anak didik dalam meretas kleptokrasi, rasa sakit kejiwaan bangsa, dan krisis multi dimensi, yang tak kunjung sembuh (Barizi, 2011). Jadi adanya pendidikan agama yang dilaksanakan sejak dini kepada anak didik sebagai usaha perintah dalam menanamkan sebuah kepercayaan dan kepribadian yang kokoh untuk masa depan yang cerah

\section{Tinjauan Secara Teknis Undang-undang Sisdiknas Nomor 20 Tahun 2003}

Undang-undang sistem pendidikan Nasional adalah merupakan produk hukum yang di dalamnya memuat tentang sistem pendidikan di Indonesia, undangundang Sisdiknas tahun 2003 disahkan di Jakarta pada 8 Juli 2003 oleh Presiden Republik Indonesia yakni Ibu Megawati Soekarnoputri. Dalam suatu muatan undang-undang tentu mempunyai beberapa kaidah hukum yang nantinya sebagai acuan untuk proses implementasi, namun terkadang pemahaman terhadap undangundang atau aturan itu identik dengan kewajiban yang mutlak harus diikuti, padahal 
secara teknis dalam undang-undang sisdiknas tahun 2003 memiliki beberapa kaidah hukum, yaitu ada tiga kaedah hukum, diantaranya adalah.

1. Besifat perintah atau suruhan, yaitu secara teknis undang undang memiliki aturan yang bersifat wajib yang harus diikuti oleh semua pihak dan juga perintah kepada masyarakat pendidikan dalam menjalankan tugasnya, seperti pada pasal 7 ayat 2 yang berbunyi "Orang tua dari anak usia wajib belajar, berkewajiban memberikan pendidikan dasar kepada anaknya."

2. Bersifat Kebolehan, yaitu suatu muatan hukum atau undang-undang yang bersifat kebolehan bagi semua pihak pendidikan dalam suatu hal, misalkan pada pasal 23 ayat 1 yang berbunyi "Pada universitas, institut, dan sekolah tinggi dapat diangkat guru besar atau profesor sesuai dengan peraturan perundang-undangan yang berlaku".

Bersifat Larangan, yaitu muatan undang-undang yang memberikan larangan kepada semua pihak pendidikan untuk melaksanakannya, hal tersebut sesuai dengan pasal 21 ayat 2 yang berbunyi "Perseorangan, organisasi, atau penyelenggara pendidikan yang bukan perguruan tinggi dilarang memberikan gelar akademik, profesi, atau vokasi”. Jadi cukup jelas bahwa adanya undang-undang sisdiknas memberikan kaidah hukum yang secara teknis mengarah kepada tiga hal, yaitu bentuk suruhan atau perintah, kebolehan dan larangan, maka dengan demikian kesadaran masyarakat terhadap kebijakan tersebut harus ditingkatkan guna mencapai tujuan pendidikan nasional.

\section{Tinjauan Terhadap Isi Undang-undang Sisdiknas Nomor 20 Tahun 2003}

Kebijakan pemerintah yang memuat tentang sistem pendidikan nasional tertuang dalam undang-undang nomer 20 tahun 2003, hal tersebut merupakan produk hukum yang secara substansial membahas isi tentang UU sistem pendidikan secara menyeluruh yang dituangkan dalam bentuk bab, pasal dan ayat sesuai dengan klasifikasi yang secara jelas akan dibahas sebagaimana berikut.

1. Pendahuluan

Dalam undang-undang sisdiknas muatan pertama secara administatif adalah pendahuluan dimana dalam pendahuluan ini undang-undang memuat bagian konsideran beserta definisi-definisi mengenai makna-makna daripada kata-kata yang terdapat dalam UU No. 20 Tahun 2003 ini. Dalam bagian pendahuluan tepatnya untuk konsideran ini UU No. 20 Tahun 2003 ditetapkan berdasarkan berbagai aspek 
pertimbangan, antara lain: pembukaan Undang-Undang Negara Republik Indonesia Tahun 1945 (UUD 1945) yang mengamanatkan bahwa Pemerintahan Negara Indonesia berperan dalam mencerdaskan kehidupan bangsa.

Selanjutnya isi daripada UUD 1945 yang mengamanatkan bahwa Pemerintah perlu untuk menyelenggarakan satu sistem pendidikan nasional, dan UU No. 2 Tahun 1989 tentang Sistem Pendidikan Nasional yang dianggap tidak memadai lagi dan perlu diganti serta perlu disempurnakan agar sesuai dengan amanat perubahan UUD Tahun 1945 serta dengan mengingat Pasal 20, Pasal 21, Pasal 28 C ayat (1), Pasal 31, dan Pasal 32 UUD Tahun 1945.

2. Pembahasan

Pada pembahasan ini secara substansial dapat dibagai menjadi tiga bagian pokok dalam muatan undang-undang Sisdiknas nomer 20 tahun 2003 yaitu sebagai berikut.

\section{a. Peserta Didik}

Pada bab ini secara umum membahas tentang hak dan kewajiaban bagi peserta didik, yang mana hak adalah suatu hal yang harus didapat oleh peseta didik, dan kewajiban adalah suatu hal yang harus dilakukan dan ditepati oleh peserta didik semenjak berada dalam lingkungan pendidikan. Misalkan pertama, hak bagi peserta didik sesuai dengan pasal 12 ayat 1 yaitu, peserta didik wajib mendapatkan pendidikan agama sesuai dengan agama yang dianutnya yang diajarkan oleh pendidik yang seagama (Tim Redaksi Sinar Grafika, 2007). Jadi dengan isi undang-undang tersebut jelas bahwa siswa atau peserta didika mempunyai hak yang harus dipenuhi oleh pemangku kebijakan pendidikan sesuai dengan peraturan di atas.

Kedua, yaitu kewajiban bahwa bagi peserta didik mempunyai kewajian dalam menjalankan proses pendidikan diantara seperti muatan undang-undang yang tercantum dalam pasal 12 ayat 2 yaitu setiap peserta didik berkewajiban menjaga norma-norma pendidikan untuk menjamin keberlangsungan proses dan keberhasilan pendidikan (Tim Redaksi Sinar Grafika, 2007).

b. Pendidik dan Tenaga Kependidikan

Dalam bab XI pasal 39 sampai pasal 44 dijelaskan bahwa tuga pendidik pada intinya adalah melaksanakan pembelajaran dan tenaga kependidikan bertugas dalam kegiatan administrasi.Selanjutnya dijelaskan pula mengenai hak dan kewajiban dari pendidik dan tenaga kependidikan. Pendidik dan tenaga 
kependidikan disini ditempatkan berdasarkan kebutuhan satuan pendidikan formal melihat dari kebutuhan daerah dimana disini pemerintah memfasilitasi segala keperluan dari pendidik dan tenaga kependidikan. Selain itu dalam hal ini dipaparkan jugamengenai ketentuan kualifikasi, promosi, penghargaan, dan sertifikasi. Pengembangan pendidik dan tenaga pendidik dalam hal ini harus mampu dikembangkan oleh pemerintah dan pemerintah daerah.

Menurut Soetjipto Guru merupakan unsur aparatur negara dan abdi negara. Karena itu, guru mutlak perlu mengetahui kebijaksanaan-kebijaksanaan pemerintah dalam bidang pendidikan, sehingga dapat melaksanakan ketentuan-ketentuan yang merupakan kebijaksanaan tersebut. Kebijaksanaan pemerintah dalam bidang pendidikan ialah segala peraturan-peratutan pelaksanaan baik baik yang dikeluarkan oleh departemen pendidikan dan kebudayaan dipusat maupun di daerah (Soetjipto, 2009).

\section{c. Sarana dan Prasarana}

Dalam bab XII pasal 45 yang terdiri dari 2 ayat dijelaskan bahwa setiap satuan pendidikan wajib menyediakan sarana dan prasarana yang mendukung keperluan pendidikan sesuai dengan pertumbuhan dan perkembangan peserta didik. Selanjutnya ketentuan yang berkaitan dengan penyediaan sarana dan prasarana ini diatur dalam peraturan pemerintah.

\section{d. Pendanaan Pendidikan}

Dalam bab XIII pasal 46 sampai pasal 49 dijelaskan bahwa pemerintah, pemerintah daerah, dan masyarakat bertanggung jawab terhadap pendanaan pendidikan dalam hal menyediakan sumber pendanaan pendidikan dengan prinsip keadilan, kecukupan, dan keberlanjutan serta pengarahannya yang sesuai dengan peraturan perundang-undangan yang berlaku, pengelolaan dana pendidikan, dan pengalokasian dana pendidikan minimal sebesar $20 \%$ dari APBN, $20 \%$ APBD dan hibah yang dialokasikan untuk dana penyelenggaraan pendidikan.

e. Kurikulum

Dalam bab X pasal 36 sampai 38 dijelaskan bahwa pengembangan kurikulum dilakukan dengan mengacu pada standar nasional pendidikan dalam rangka mewujudkan tujuan pendidikan dengan prinsip diversifikasi sesuai dengan potensi daerah dan peserta didik. Dalam kurikulum ini harus memuat nilai-nilai khusus yang telah disepakati dalam menjamin tercapainya tujuan pendidikan 
nasional. Selanjutnya dalam dalam struktur kurikulum pada pendidikan dasar, menengah, bahkan tinggi ini harus memuat beberapa muatan wajib berupa matapelajaran yang harus disampaikan dalam penyelenggaraan kegitan pendidikan yang dilaksanakan pada jenjang-jenjang tersebut. Lebih lanjut lagi, bahwa kerangka dasar dan struktur kurikulum pendidikan dasar dan menengah ditetapkan oleh pemerintah, sedangkan kerangka dasar dan struktur kurikulum pendidikan tinggi dikembangkan oleh perguruan tinggi itu sendiri dengan mengacu pada standar nasional pendidikan untuk setiap program studinya.

f. Hubungan Sekolah dan Masyarakat

Dalam bab XV pasal 54 sampai pasal 56 dijelaskan bahwa hubungan sekolah dan masyarakat dalam hal ini salah satunya berupa peran serta masyarakat dalam pendidikan meliputi peran serta perseorangan, kelompok, keluarga, organisasi profesi, pengusaha, dan organisasi kemasyarakatan dalam penyelenggaraan dan pengndalian mutu pelayanan pendidikan. Melihat terdapatnya hubungan sekolah dan masyarakat maka dalam hal ini perlu adanya penyelenggaraan pendidikan berbasis masyarakat dengan mengembangkan dan melaksanakan kurikulum dan evaluasi pendidikan, serta manajemen dan pendanaannya sesuai dengan standar nasional pendidikan.

Menurut Uhar Suharsaputra membangun hubungan menjadi sangat penting karena akan memberikan kontribusi bagi modal sosial yang juga penting bagi penciptaan keunggulan kompetitif organisasi (Suharsaputra, 2015).

Dalam bahasa yang lebih dinamis dikatakan bahwa lembaga pendidikan dan masyarakat bukan sekedar menjalin hubungan, tetapi lebih kepada komunikasi, dan keluasan makna ini akan berdampak terhadap harmonisasi hubungan sekolah dan masyarakat sehingga pada gilirannya dapat tercipta jika masing-masing elemen yang menjadi pelengkap hubungan tersebut dapat terpelihara serta masing-masing memberikan dukungan satu dengan yang lainnya (Tim Dosen Administrasi Pendidikan UPI, 2011).

\section{Penutup}

Penutup adalah bagian akhir dalam suatu undang-undang yang mana pada bagian penutup ini dalam undang-undang No. 20 Tahun 2003 terdiri beberapa ketentuan yaitu: 
a. Ketentuan pidana yaitu berisi mengenai beberapa tindakan pidana baik berupa kurungan maupun denda terhadap segala tindakan yang melanggar peraturan mengenai penyelenggaraan pendidikan dari berbagai kegiatannya, hal tersebut diamuat dalam bab XX mulai dari 67 sampai pasal 71.

b. ketentuan peralihan yaitu mengenai pemberlakuan penyelenggaraan pendidikan yang pada saat undang-undang ini diberlakukan belum berbentuk badan hukum pendidikan,waktu perijinan selambat-lambatnya 2 tahun bagi satuan pendidikan formal yang telah berjalan namun belum memiliki ijin, dan pemberlakuan peraturan pelaksanaan UU No. 2 Tahun 1989 selama tidak bertentangan dan belum diganti berdasarkan undang-undang ini,hal tersebut dibahas dalam bab XXI mulai dari pasal 72 sampai pasal 74.

c. ketentuan penutup yaitu dalam ketentuan ini dipaparkan mengenai peraturan perundang-undangan yang tidak berlaku lagi setelah UU ini diterbitkan, yang dibahas bab pada XXII mulai pasal 75 sampai pasal 77 (Departemen Pendidikan Nasional, 2003).

Dari penjelasan di atas dapat dipahami bahwa kajian secara substansial dari muatan undang-undang Sisdiknas nomer 20 tahun 2003 secara umum meliputi pendahuluan, pembahasan, dan penutup, yang setiap komponen mempunyai pasal dan ayat yang dijelaskan secara rinci.

\section{Analisis terhadap Isi UU Sisdiknas Nomor 20 Tahun 2003}

Ketika masyarakat semakin kehilangan kepercayaan terhadap potensi dan peran pendidikan, ketika pada saat yang sama kebijakan serta pengelolaan pendidikan lebih terpusat pada hal-hal yang trivial, dan bukan pada hal-hal yang fundamental, maka gabungan dari dua kondisi itu saja sudah memastikan bahwa pendidikan akan semakin menjauh dari misi utama (Surakhmat, 2009). Maka kebijakan sistem pendidikan merupakan langkah strategis pemerintah untuk menumbuhkan kepercayaan masyarakat terhadap pendidikan yang berbartabat, tidak dipandang miring sebagai produk hukum yang nantinya menjadi acuan bersama, dan tidak menuai masalah dalam implementasinya sebagai mana UU sisdiknas 2003.

Selanjutnya pada bab ini akan dijelaskan secara mendalam terkait UU sisdiknas 2003 dengan kajian analisis kritis, yaitu dengan memahami pasal dan ayat yang ada dalam muatan UU sisdiknas 2003, yang mana pada muatan isi dalam 
peraturan sangat menarik sekali jika dipahami secara mendalam, pro dan kontra terhadap kebikajakan tersebut secara umum telah dibahas pada bab sebelumnya, namun pada bab ini pembahasan mengenai analisis kritis terhadap kebijakan UU Sisdiknas 2003 akan lebih spesifik, penulis merangkum beberapa persoalan yang yang secara substansial penting untuk diketahui.

\section{Analisis Terhadap Kurikulum}

Kurikulum merupakan perantara utama untuk menuju kesuksesan pendidikan, karena dalam keberhasilan pendidikan akan terlihat manakala kurikulum yang dijalankan relevan dengan tuntutan zaman dan masyarakat sehingga pendidikan akan tanpak sesuai dengan tujuan pendidikan nasional, namun kurikulum yang akan menjadi jembatan pendidikan diharuskan bersifat dinamis, yaitu harus mengalami perubahan dan pengembangan-pengembangan sesuai tuntutan yang ada, esensinya kurikulum diharuskan mampu menjawab persoalan yang menjadi hambatan dalam meningkatkan kualitas pendidikan di indonesia, dengan demikian perlu kiranya untuk menyeimbangkan antara perkembangan zaman dan pengembangan kurikulum, yang dalam konteks ini bagaimana kurikulum harus diadakan penyempurnaan atau perbaikan kurikulum dalam rangka mengatasi segala persoalan yang terjadi dalam pendidikan.

Dalam upaya penyempurnaan atau perbaikan kurikulum tentu tidak mudah dilakukan bagi elemen atau pihak terkait yang berwajib, karena dalam kurikulum tentu mempunyai beberapa model dan orientasi yang sama-sama berbeda, hal tersebut menjadi kajian penting untuk dipahami karena model dan orientasi tersebut akan mempengaruhi terhadap paradigma kurikulum yang akan diperbaiki, selain hal tersebut tentu banyak point-point yang harus dijadikan bahan pertimbangan dalam upaya perbaikan kurikulum agar dapat membuahkan hasil yang sempurna. Namun samsapai saat ini pendidikan di Indonesia dilanda penyakit dilema yang cukup serius, hal tertesebut dibuktikan dengan adanya perubahan kurikulum yang terus terjadi tanpa adanya analisis implementasi yang mendalam, sehingga kurikulum di Indonesia tidak konsisten terhadap apa yang ia capai.

Pribahasa yang begitu masyhur dikalangan masyarakat intelektual adalah “jika mentrinya berubah maka kurikulumnya berubah" kalimat tersebut merupakan kesimpulan masyarakat terhadap sistem pendidikan di indonesia yang selalu dilema, sebagai contoh kecil saat ini, adanya kebijakan pemerintah terkait implementasi kurikulum 2013 ternyata tidak membuahkan hasil yang signifikan, dampak dari 
adanya kegagalan tersebut tentu membuat kerugian yang begitu besar terhadap anggaran pendidikan. Maka dari itu pemerintah harusnya melakukan pengkajian dengan berbagai pertimbangan-pertimbangan terkait dengan realisasi kurukulum yang ada.

Pada bab II pasal 3 UU Sisdiknas 2003 telah dijelaskan secara detail bahwa: "Pendidikan nasional berfungsi mengembangkan kemampuan dan membentuk watak serta peradaban bangsa yang bermartabat dalam rangka mencerdaskan kehidupan bangsa, bertujuan untuk berkembangnya potensi peserta didik agar menjadi Marusia yang beriman dan bertakwa kepada Tuhan Yang Maha Esa, berakhlak mulia, sehat, berilmu, cakap, kreatif, mandiri, dan menjadi warga negara yang demokratis serta bertanggung jawab". Pasal tersebut memberikan gambaran bahwa adanya perumusan undang-undang baru tidak lain bahwa bagaimana pendidikan nasional mampu mencerdaskan kehidupan anak bangsa, namun disisi lain ada beberapa penyimpangan dan perbedaan makna dengan rumusan tentang dasar-dasar pendidikan dan pengajaran disekolah yang tercantum dalam UU No.4 Tahun 1950 pasal 3 yang berbunyi: "tujuan pendidikan dan pengajaran ialah membentuk manusia susila yang cakap dan dan warga negara yang demokratis serta bertanggung jawab tentang kesejahteraan masyarakat dan tanah air".

Menurut Tilaar bahwa dalam rumusan UU no. 20 tahun 2003 terasa kurang jelas orientasi serta tujuan pendidikan nasional karena tidak menyinggung secara eksplisit mengenai kecerdasan manusia indonesia sebagaimana yang diminta oleh UUD 1945 (Tilaar, 2005). Jadi rumusan tentang tujuan sistem pendidikan nasional lebih spesifik UU sisdiknas no.4 tahun 1950 dibandingkan dengan tujuan pada UU sisdiknas no. 20 tahun 2003.

\section{Analisis terhadap Pasal 5 ayat 3 (Tentang pendidikan layanan Khusus)}

"Warga negara di daerah terpencil atau terbelakang serta masyarakat adat yang terpencil berhak memperoleh pendidikan layanan khusus".

Penjelasan pasal di atas dilihat dari prinsip keadilan tentu cenderung tidak menyamakan hak dari setiap warga negara untuk memperoleh pendidikan yang sama, klasifikasi terhadap daerah merupakan pertanda bahwa prinsip persamaan terhadap bangsa tidak tercermin, maka jika pada pasal di atas terjadi pengkhusususan terhadap masyarakat terpencil atau terbelakang maka hal tersebut terjadi diskriminasi pelayanan publik secara utuh. Idealnya sistem pendidikan nasional harus terhindar dari disparitas bangsa, jika undang-undang tersebut di 
maknai secara kontekstual maka nilai-nilai kesetaraan serta keadilan bangsa akan terhapus dengan sendirinya.

\section{Analisis terhadap Pasal 5 ayat 5 (Tentang pendidikan sepanjang hayat)}

"Setiap warga negara berhak mendapat kesempatan meningkatkan pendidikan sepanjang hayat".

Dalam penjelasan pasal 5 ayat 5 ini dijelaskan mengenai kesempatan warga negara untuk meningkatkan pendidikan sepanjang hayat. Namun pada kenyataannya pada pendidikan dasar dan menengah tersebut terdapat pembatasan usia dalam memperoleh pendidikan. Jadi, ayat tersebut tidak selaras dengan kenyataan yang ada.

Bertolah pemahaman di atas pendidikan sepanjang hayat merupakan konsepsi yang sangat menarik untuk diperbincangkan, karena hal tersebut merupakan esensi manusia dalam menuntut ilmu, dalam islam menganjurkan bahwa manusia menuntut ilmu dimulai dari buayan sang ibu sampai ke liang lahat. Jadi kesempatan bangsa indonesia untuk mengenyam pendidikan tidak terbatas oleh waktu, kecuali ia mennggal dunia. Maka dengan demikian perlunya kesadaran masyarakat terhadap pasal di atas agar pendidikan di indonesia terus berkembang, tidak adanya istilah anak putus sekolah.

\section{Analisis terhadap Pasal 7 ayat 2 (tentang kewajiban orang tua memberikan pendidikan )}

"Orang tua dari anak usia wajib belajar berkewajiban memberikan pendidikan dasar pada anaknya"

Dalam ayat tersebut dijelaskan mengenai kewajiban orangtua dalam memberikan pendidikan dasar pada anaknya. Namun akan lebih baik bila dalam ayat tersebut dijelaskan pula mengenai sanksi daripada pelanggarannya. Karena bila dilihat pada kondisi pendidikan saat ini sangat banyak orangtua yang tidak mendukung pendidikan anaknya, mereka lebih menyuruh anaknya untuk bekerja dalam membantu ekonomi keluarga daripada mengikuti wajib belajar 9 tahun.

Pada penjelasan tentang ketentuan pidana yang tertulis dalam bab XX tidak dijelaskan tentang pidana terhadap pihak yang melanggar atas ketentuan kewajiban, jika UU Sisdiknas ingin berdiri secara Profesional maka seharusnya segala bentuk penyimpangan yang melanggar dengan ketentuan wajib yang telah 
diamanatkan harus ada tidakan yang harus diberikan kepada semua masyarakat yang tidak mentaatinya.

\section{Analisis terhadap Pasal 31 ayat 3 (Tentang Pendidikan Jarak Jauh)}

"Pendidikan jarak jauh diselenggarakan dalam berbagai bentuk, modus, dan cakupan yang didukung oleh sarana dan layanan belajar serta sistem penilaian yang menjamin mutu lulusan sesuai dengan standar nasional pendidikan."

Dalam pasal 31 ayat 3 tersebut kurang dipahami mengenai bentuk dari pendidikan jarak jauh itu seperti apa, karena dalam pasal 31 ayat 3 tersebut tidak diuraikan contoh bentuk pendidikan jarak jauh tersebut seperti yang ada di pendidikan keagamaan. Sampai saat ini realisasi dari adanya undang-undang Sisdiknas ayat 31 tersebut tidak terlihat, maka jelas adanya peraturan tersebut perlu dilakukan pengkajian ulang, sehingga undang-undang benar-benar menjadi acuan oleh setiap warga satuan pendidikan.

\section{Analisis Terhadap Pasal 34 ayat 1 (Tentang Wajib Belajar)}

"Setiap warga negara yang berusia 6 tahun dapat mengikuti program wajib belajar".

Dalam pasal 34 ayat 1 tersebut disebutkan bahwa warga negara yang berusia 6 tahun dapat mengikuti program wajib belajar. Sedangkan pada pasal 6 ayat 1 disebutkan setiap warga negara wajib mengikuti pendidikan dasar mulai usia 7 tahun. Hal ini menunjukkan tidak adanya sinkronisasi antara kedua pasal tersebut dalam menentukan usia minimal pendidikan dasar, karena terdapat dua standar usia yang berbeda. Jika undang-undang mengisyaratkan demikian maka seharusnya ada tindakan tegas dari pemerintah bagi warga negara Indonesia yang berusia 6 tahun yang tidak mengikuti program wajib belajar, sehingga tidak ada istilah anak tidak sekolah.

\section{Analisis Terhadap Pasal 34 ayat 2 (tentang Bebas biaya)}

"Pemerintah dan pemerintah daerah menjamin terselenggaranya wajib belajar minimal pada jenjang pendidikan dasar tanpa memungut biaya".

Pada pasal tersebut dianggap tidak sesuai dengan kondisi pendidikan di Indonesia pada saat ini karena dilapangan bisa dilihat bahwa di sekolah swasta itu pemerintah tidak sepenuhnya mendukung pembebasan biaya pendidikan. adanya beberapa lembaga pendidikan yang masih memungut biaya pendidikan tentunya 
harus ada ketegasan dari pemirintah dalam mengupayakan terlaksananya pasal 34 di atas

8. Analisis Terhadap Pasal 50 ayat 1 (Tentang Tanggung jawab Menteri)

"Pengelolaan sistem pendidikan nasional merupakan tanggung jawab menteri".

Ketidak jelasan pada pasal di atas terdapat pada keumuman bahasa yang diuraiakan, di mana menteri yang dimaksud di atas tidak dijelaskan secara detail, sehingga pertanyaan akan muncul mengenai menteri tersebut.

\section{Analisis terhadap Pasal 50 ayat 3 (Tentang penyelenggaraan Satuan Pendidikan Bertaraf Internasional)}

"Pemerintah dan/atau pemerintah daerah menyelenggarakan sekurangkurangnya satu satuan pendidikan pada semua jenjang pendidikan untuk dikembangkan menjadi satuan pendidikan yang bertaraf internasional".

Realitas sosial yang terjadi dilapangan bahwa warga Indonesia tidak terhindar dari krisis ekonomi yang mendera, maka kebijakan dari pada pasal di atas tidak bisa menciptakan pendidikan yang sama untuk seluruh warga negara. Karena dengan adanya kebijakan penyelenggaraan pendidikan bertaraf internasional tersebut yang dapat memanfaatkan hanyalah orang-orang dengan kelas ekonomi yang tinggi, padahal esensinya pendidikan.

Selain itu kebijakan pemerintah menyelenggarakan sekolah bertaraf internasional ini juga dapat diplesetkan menjadi sekolah bertarif internasional, biaya pendidikan yang mahal membuat masyarakat berfikir berbalik tentang pendidikan bertaraf internasional menjadi pendidikan bertaraf internasional. Dari keterbatan ekonomi bangsa yang semuanya secara kemampuan tidak sama, maka pelaksanaan pendidikan bertaraf internasional mencederai terhadap asas keadilan dan persamaan terhadap bangsa, karena hanya orang yang beruang saja yang bisa mnyekolahkan anaknya kelembaga tersebut, sedangkan kaum miskin tetap saja bersimpuh di tempat yang begitu memperhatinkan, kesempatan menuju sekolah unggul hanya menjadi mimpi belaka, dengan dengan demikian dimakah letak bentuk pemerataan pendidikan yang berasaskan demokrasi tidak dapat dipungkiri dari adanya hal tersebut adan terjadi disparitas sosial yang mengarah kepada diskriminasi bangsa. 
Menurut Soetjipto Guru merupakan unsur aparatur negara dan abdi negara. Karena itu, guru mutlak perlu mengetahui kebijaksanaan-kebijaksanaan pemerintah dalam bidang pendidikan, sehingga dapat melaksanakan ketentuan-ketentuan yang merupakan kebijaksanaan tersebut. Kebijaksanaan pemerintah dalam bidang pendidikan ialah segala peraturan-peratutan pelaksanaan baik baik yang dikeluarkan oleh departemen pendidikan dan kebudayaan dipusat maupun di daerah (Soetjipto, 2009).

\section{Analisis terhadap pasal 35 (Tentang Standar Nasional Pendidikan)}

"Standar nasional pendidikan terdiri atas standar isi, proses, kompetensi lulusan, tenaga kependidikan, sarana dan prasarana, pengelolaan, pembiayaan, dan penilaian pendidikan yang harus ditingkatkan secara berencana dan berkala".

Pendidikan merupakan suatu kegiatan yang berproses, dimana setiap sesuatu yang berproses mempunyai tujuan tertentu yang harus dicapai, pendidikan sebagai proses yang bertujuan harus memiliki ukuran tertentu untuk mencapai tujuan, maka dari itu dalam kontek pendidikan nasional harus mempunyai standar yang harus dijadikan ukuran sejauh mana keberhasilan pendidikan dalam mewujudkan tujuan pendidikan yang tertulis dalam UUD 1945 yaitu untuk mencerdaskan anak bangsa.

Maka dari itu standar merupakan hal yang sangat diperlukan dalam sistem pendidikan nasional, seperti yang ditulis oleh Tilar bahwa:

a. Standarisasi pendidikan nasional merupakan suatu tuntutan politik, sebagai negara kesatuan Republik Indonesia kita memerlukan Yardstick untuk menilai sejauh mana warga negara indonesia itu mempunyai visi yang sama, pengetahuan dan keterampilan yang dapat mengembangkan negara kesatuan tersebut.

b. Standarisasi pendidikan nasional merupakan suatu tuntutan globalisasi. Dunia dewasa ini telah merupakan suatu kampung global sehingga satu nega dapat bersembunyi lagi. Didalam kehidupan global terjadi persaingan yang semakin lama semakin tajam, oleh sebab itu setiap warga negara perlu mengangkat dirinya sendiri didalam kehidupan yang penuh dengan persaingan. Kehidupan yang penuh dengan persaingan bukan berarti kehidupan yang penuh dengan permusuhan tetapi terus menerus memperbaiki diri dengan meningkatkan kemampuan diri agar agar supaya tidak menjadi budak dari bangsa-bangsa lain. 
c. Standarisasi pendidikan nasional merupakan suatu tuntutan dari kemajuan (progres), setiap negara tidak menginginkan negaranya tertinggal dari bangsa-bangsa yang lain. Untuk menjadi anggota dari negara maju tentunya diperlukan kualitas sumber daya manusianya yang tinggi yang bukan hanya sebagai konsumer dari produk-produk negar maju lainnya tetapi juga dapat berpartisipasi di dalam meningkatkan mutu kehidupan manusia (Tilar, 2006)

Standarisasi nasional pendidikan merupakan hal yang sangat penting untuk dirumuskan, menurut Aqib standar nasional pendidikan memuat kriteria minimal tentang komponen pendidikan yang memungkinkan setiap jenjang jalur pendidikan mengembangkan pendidikan secara optimal sesuai dengan karakteristik dan kekhasan nprogramnya (Aqib, 2002). dimana dari beberapa poin di atas dapat tercermin bahwa pendidikan nasional sebagai tolok ukur dari kemajuan suatu bangsa. yang mana dengan adanya standarisasi pendidikan diharapkan pendidikan di indonesia mempunyai target yang jelas yang sesuai dengan tujuan pendidikan nasional.

\section{Kesimpulan}

Dari pembahasan di atas dapat ditarik sebuah kesimpulan bahwa implementasi UU sisdiknas 2003 merupakan kebijakan pemerintah yang dijadikan dasar hukum dalam sistem pendidikan Nasional, yang mana dalam UU sisdiknas tersebut secara teknis memuat tentang perintah, kebolehan, dan larangan, maka secara substansial tiga hukum tersebut berada dalam UU sisdiknas pada bagian isi yang meliputi pendahuluan, pembahaan dan penutup.

Namun secara kritis, implementasi UU sisdiknas 2003 secara teoritis mengalami perdebatan panjang, yang menyoal tentang pasal dan ayat yang terkandung didalamnya. Dari sebagian pasal bertentangan dengan pasal yang lain, maka UU sisdiknas perlu pembaharuan kembali agar hal tersebut teidak menuai banyak kontoversi. Maka dengan demikian implementasi UU sisdiknas 2003 merupakan kebijakan pemerintah yang harus disesuaikan dengan keadaan sekarang melalui anasis lebih mendalam atas kebutuhan bangsa sesuai dengan tantangan globalisasi. 


\section{Referensi}

Aqib, Z. (2002). Profesionalisme Guru dalam Pembelajaran. Surabaya: Insan Cendekia.

Barizi, A. (2011). Pendidikan Integratif Akar Tradisi Dan Integrasi Keilmuan Pendidikan Islam. Malang: UIN MALIKI Press.

Departemen Pendidikan Nasional. (2003). Undang-Undang RI Nomor Nomor 20 Tahun 2003. Jakarta: Depdiknas.

Komite Rekonstruksi Pendidikan DIY. (2009). Menuju Jati Diri Pendidikan Yang Mengindonesia. Yogyakarta: Gadjah Mada Univercity Press.

Nawawi, H. (2004). Kebijakan Pendidikan di Indonesia di Tinjau dari Sudut Hukum. Yogyakarta: Gadjah Mada University Press.

Rohman, A. (2010). Education Policy In Decentralization Era. Yogyakarta: Pustaka Pelajar.

Soetjipto. (2009). Profesi Keguruan. Jakarta: Rineka Cipta.

Suharsaputra, U. (2015). Manajemen Perguruan Tinggi Strategi Menghadapi Perubahan. Bandung: PT. Refika Aditama.

Surakhmat, W. (2009). Pendidikan Nasional Strategi dan Tragedi. Jakarta: PT. Kompas Media Nusantara.

Susetio, B. (2005). Politik Pendidikan Penguasa. Yogyakarta: Lkis.

Tilaar, H. A. . (2005). Manifesto Pendidikan Nasional Tinjauan dari Perspektif Postrnodernisme dan Studi Kultural. Jakarta: Kompas.

Tilar, H. A. R. (2006). Standarisasi Pendidikan Nasional; Suatu Tinjauan Kritis. Jakarta: PT. Rineka Cipta.

Tim Dosen Administrasi Pendidikan UPI. (2011). Manajemen Pendidikan. Bandung: Alfabeta.

Tim Redaksi Sinar Grafika. (2007). Undang-Undang Sistem Pendidikan Nasional Nomor 20 Tahun 2003. Jakarta: Sinar Grafika. 